\title{
ANALISIS PERGERAKAN VERTIKAL TITIK PANTAU JEMBATAN PENGGARON, KABUPATEN SEMARANG, PROPINSI JAWA TENGAH
}

\author{
Yacob V. Hayer ${ }^{1}$, T. Aris Sunantyo ${ }^{2}$, Nurrohmat Widjajanti ${ }^{3}$. \\ 1) Jurusan Teknik Sipil, Politeknik Negeri Kupang \\ 2,3) Departemen Teknik Geodesi dan Geomatika, Universitas Gadjah Mada. \\ Email: hayeryopi27@gmail.com
}

\begin{abstract}
Penggaron bridge toll highway is located in road Semarang-Ungaran, $20^{\text {th }}$ kilometer in the Susukan region, East Ungaran, Semarang regency, Central Java province. Penggaron bridge has a $400 \mathrm{~m}$ length and nine pillars that support the weight of the bridge. This bridge has began operation since 2010. The bridge visually deformed as indicated by small cracks in the pillars of the bridge. Natural factors such as unstable soil conditions are suspected as the cause of deformation. To minimize and prevent damage that may occur on the bridge then the Penggaron bridge deformation monitoring should be performed. Therefore, this study analyze the vertical movement on the Penggaron bridge using height difference observation data by waterpass in 2014 s.d. 2015 . This study used four epoch height different observation data on the 18 bridge monitoring points. The 18 monitoring bridges points was tied to two reference points around the bridge. These observation data is processed by Least Squares Adjustment parameter method to get the height and its standard deviation, vertical movement and its standard deviation, vertical movement velocity and its standard deviation as well as average velocity and average acceleration on every bridge monitoring points on each epoch. The next step includes the computation and analysis of vertical movement, as well as the significance of two parameter different test. The results of this study are the vertical movement vector of the 18 monitoring points with magnitude from $3,1 \mathrm{~mm}$ to $170,3 \mathrm{~mm}$ with the majority down direction. The vertical movement velocity has a range between $3,05 \mathrm{~mm} / \mathrm{month}$ to $89,35 \mathrm{~mm} / \mathrm{month}$ with the movement direction tends to downward. The average velocity of vertical movement for epoch I and II is 7,08 $\mathrm{mm} / \mathrm{month}$, epoch II and III is $4,93 \mathrm{~mm} / \mathrm{month}$, epoch I and III is $6,00 \mathrm{~mm} / \mathrm{month}$, epoch III and IV is 6,03 $\mathrm{mm} / \mathrm{month}$, epoch I and IV is $1,29 \mathrm{~mm} / \mathrm{month}$ with the movement direction tends to downward. The average acceleration of vertical movement for epoch I and II is $7,08 \mathrm{~mm} / \mathrm{month}^{2}$, epoch II and III is $4,93 \mathrm{~mm} / \mathrm{month}^{2}$, epoch I and III is $3,00 \mathrm{~mm} / \mathrm{month}^{2}$, epoch III and IV is $6,03 \mathrm{~mm} / \mathrm{month}^{2}$. The majority of the significance of two parameter different test parameters is rejected, it means that monitoring points had a significant movement.
\end{abstract}

Keywords : Penggaron bridge, waterpass, the height difference, least squares adjustment, vertical movement, velocity.. 



\section{PENDAHULUAN}

Infrastruktur memegang peranan penting sebagai salah satu roda penggerak pertumbuhan ekonomi. Ketersediaan infrastruktur seperti jalan, jembatan, bandara, pelabuhan merupakan salah satu faktor pendukung yang dapat meningkatkan tingkat perekenomian suatu daerah atau negara.

Adanya jembatan memungkinkan suatu jalan melintasi sungai/saluran air, lembah atau melintasi jalan lain yang tidak sama tinggi permukaannya dan juga memungkinkan pengguna untuk dapat menghemat waktu dan biaya dalam menempuh suatu perjalanan. Jembatan berfungsi untuk menyeberangkan orang dan kendaraan, karena fungsinya tersebut jalan dilalui oleh berbagai-bagai tipe dan jenis kendaraan dan dengan berjalannya waktu maka dapat terjadi penurunan kemampuan atau kondisi dari jembatan. Untuk meminimalisir dampak yang mungkin timbul akibat penurunan kemampuan tersebut perlu dilakukan pemantauan pergerakan pada jembatan yang dilakukan dengan metode dan alat-alat yang sesuai.

Jembatan Penggaron terletak di ruas jalan tol Semarang-Ungaran di km 20 di wilayah Susukan, Ungaran Timur, Kabupaten Semarang, Provinsi Jawa Tengah. Jembatan Penggaron memiliki panjang $400 \mathrm{~m}$ dan sembilan pilar yang menopang badan jembatan. Usia jembatan ini tergolong masih baru dan mulai dioperasikan pada tahun 2010, namun jembatan ini secara visual mengalami deformasi yang ditunjukkan dengan retakanretakan kecil pada beberapa pilar jembatan.

Penelitian dengan subjek deformasi Jembatan Penggaron telah dilakukan oleh beberapa peneliti diantaranya : Utomo (2013) dengan metode close range photogrametry (CRP) dengan titik pemantauan pada pilar-pilar jembatan, Safi'i (2014) melakukan penelitian menggunakan GPS dual frequency untuk mengetahui pergeseran 2D yang terjadi pada titik kontrol pengamatan jembatan pada tahun 2014 menggunakan metode relatif statik yang diikatkan dengan titik kontrol horizontal orde satu Badan Informasi Geospasial (BIG) Tugu Muda, Semarang.

Penelitian-penelitian tersebut dapat mendeteksi pergerakan yang terjadi pada titik pengamatan yang terdapat di sekitar Jembatan Penggaron, namun pergerakan yang dipantau hanya pergerakan horizontal dan dilakukan pada titik-titik kontrol dan pilar pada jembatan penggaron. Utomo (2013) melakukan pemantauan deformasi dalam arah $3 \mathrm{D}$, namun keterbatasan metode CRP dan jarak antar kala yang rapat yaitu satu hari merupakan kelemahan pada penelitian terdahulu. Belum adanya perhitungan dan analisis pergerakan vertikal (1D) dengan titik-titik pantau yang terdapat pada permukaan jalan sebelum dan sesudah jembatan dan pada permukaan jalan pada Jembatan Penggaron menjadikan perhitungan dan analisis ini perlu dilakukan.

Analisis pergerakan vertikal titik pantau jembatan diharapkan dapat mengidentifikasi nilai, arah, kecepatan dan percepatan pergerakan vertikal jembatan yang diamati. Penggunaan hitungan kuadrat terkecil memungkinkan untuk mendapatkan nilai pergerakan vertikal yang mewakili kondisi sebenarnya pada jembatan. Oleh karena itu, penelitian ini melakukan analisis pergerakan vertikal yang terjadi pada Jembatan Penggaron menggunakan data pengamatan beda tinggi hasil pengukuran sipat datar.

\section{METODE PENELITIAN Pengolahan data pengamatan}

Data yang digunakan pada penelitian ini adalah data pengamatan beda tinggi pada empat kala pengamatan yaitu pada kala I (Januari 2014), kala II (Februari 2014), kala III (Maret 2014) dan kala IV (Maret 2015) dengan metode sipat datar. Pengamatan beda tinggi dilakukan pada titik-titik pantau yang berjumlah 18 (delapan belas) titik pada permukaan jalan sebelum dan sesudah jembatan dan pada permukaan jalan pada jembatan.

Pengolahan data pengamatan dilakukan dengan hitung kuadrat terkecil metode parameter dengan Matlab. Pengolahan data dilakukan dengan membuat program berupa $M$-file yang berisi sederetan command yang ditulis sebagai script yang mempermudah dalam proses hitungan.

Sebelum melakukan proses pengolahan data, dilakukan screening data untuk mendeteksi apakah masih ada kesalahan sistematik maupun blunder yang mungkin terdapat pada data hasil pengukuran dengan metode sipat datar. Screening data pengukuran ini dilakukan menurut Standar Nasional Indonesia-Jaring Kontrol Vertikal (SNIJKV).

Pengolahan data pengamatan dilakukan dalam beberapa tahapan yaitu perhitungan tinggi titik pantau, perhitungan vektor pergerakan serta perhitungan kecepatan dan percepatan rata-rata. Uji Statistik

Uji statistik dilakukan setelah perhitungan tinggi titik pantau dan setelah perhitungan vektor pergerakan vertikal.

Setelah hitung perataan dilakukan, untuk menguji atau mengetahui apakah model matematik dan pemberian bobot telah benar, dan juga untuk mengetahui apakah terdapat kesalahan kasar pada data ukuran dilakukan uji statistik. Uji statistik yang digunakan setelah hitung perataan adalah uji global dan data snooping.

Uji statistik setelah perhitungan vektor pergerakan adalah uji signifikansi beda dua parameter untuk mengetahui signifikansi perbedaan koordinat titik-titik pantau antar dua kala (Widjajanti, 2010). 


\section{HASIL DAN PEMBAHASAN}

\section{Hasil Screening Data Beda Tinggi}

Pada penelitian ini menggunakan toleransi sesuai dengan SNI-JKV. Dari pemeriksaan data beda tinggi kesalahan penutup untuk semua kala memenuhi toleransi untuk kelas LB. Berdasarkan data hasil pengukuran dengan total jarak $(\mathrm{d})=1,79$ $\mathrm{km}$ didapatkan bahwa nilai toleransinya kesalahan penutup beda tinggi adalah sebesar $15,1 \mathrm{~mm}$, yang didapat melalui hitungan $8 \mathrm{~mm} \times \sqrt{d(\mathrm{Km})}$.

Hasil pengukuran menunjukkan nilai selisih beda tinggi pergi dan pulang untuk semua kala lebih kecil dari toleransi yang diijinkan sebesar $15,1 \mathrm{~mm}$. Hal ini menunjukkan bahwa selisih beda tinggi pergi dan pulang pada semua kala masih memenuhi toleransi yang disyaratkan.

\section{Hasil Uji Statistik}

Uji statistik terdiri dari uji global dan data snooping. Hasil uji global menunjukkan untuk setiap kala diterima. Hal ini berarti bahwa model matematik, proses linearisasi dan pemberian bobot telah benar dan data ukuran tidak mengandung blunder. Karena hasil dari uji global diterima maka data snooping dalam penelitian ini tidak dilakukan.

\section{Hasil Pengolahan Data Ukuran Sipat Datar}

Dari hasil pengolahan data ukuran sipat datar didapatkan tinggi dan ketelitian tinggi titik pantau pada masing-masing kala. Berdasarkan pengolahan pada masing-masing kala simpangan baku pada kala satu memiliki rentang nilai $0,6 \mathrm{~mm}$ s.d. 2,0 mm. Simpangan baku pada kala dua memiliki rentang nilai $1,5 \mathrm{~mm}$ s.d. $2,3 \mathrm{~mm}$. Simpangan baku pada kala tiga memiliki rentang nilai $0,9 \mathrm{~mm}$ s.d. $3,3 \mathrm{~mm}$ Simpangan baku pada kala empat memiliki rentang nilai $2,3 \mathrm{~mm}$ s.d. 8,1 $\mathrm{mm}$.

Berdasarkan hasil pengolahan data ukuran, simpangan baku semua titik pantau pada kala I memiliki tren nilai yang paling kecil sedangkan simpangan baku pada kala IV memiliki tren nilai yang paling besar hal ini didukung oleh hasil screening data yang menunjukkan kesalahan penutup pada kala IV memiliki nilai paling besar diantara kala lainnya. Hal ini berarti data pada kala IV memiliki ketelitian paling rendah. Hal ini kemungkinan disebabkan masih adanya kesalahan sistematik pada data hasil pengukuran namun nilai simpangan baku tersebut masih memenuhi toleransi sesuai kelas LB SNI-JKV $(<15,1 \mathrm{~mm})$.

\section{Hasil Hitungan Pergerakan Vertikal Antar Kala}

Pergerakan vertikal antar kala adalah hasil selisih tinggi antar kala sesuai dengan skenario antar kala yang sudah ditentukan. Pada penelitian ini pergerakan vertikal dihitung antara kala I (Januari 2014) dan kala II (Februari 2014) dengan rentang waktu antar pengamatan satu bulan. Kala I (Januari 2014) dan kala III (Maret 2014) dengan rentang waktu antar pengamatan dua bulan. Kala I (Januari 2014) dan Kala IV (Maret 2015) dengan rentang waktu antar pengamatan 14 bulan. Kala II (Februari 2014) dan kala III (Maret 2014) dengan rentang waktu antar pengamatan satu bulan. Kala III (Maret 2014) dan kala IV(Maret 2015) dengan rentang waktu antar pengamatan satu bulan.

1. Hasil hitungan pergerakan vertikal antar kala I dan II

Nilai pergerakan vertikal titik pantau jembatan antar kala I dan II memiliki rentang nilai -3,04 $\mathrm{mm}$ s.d. $-50,6 \mathrm{~mm}$. Hasil pergerakan vertikal yang ditunjukkan 18 titik pantau jembatan memiliki tren pergerakan seragam turun dengan titik $P_{8 k a n a n}$ merupakan titik dengan penurunan paling besar, sedangkan titik $P_{0 k a n a n}$ merupakan titik dengan penurunan paling kecil.

2. Hasil hitungan pergerakan vertikal antar kala II dan III

Nilai pergerakan vertikal titik pantau jembatan antar kala II dan III memiliki rentang nilai $-1,08$ $\mathrm{mm}$ s.d. $-32,6 \mathrm{~mm}$. Hasil pergerakan vertikal yang ditunjukkan 18 titik pantau jembatan memiliki tren pergerakan seragam turun dengan titik $\mathrm{P}_{8}$ merupakan titik dengan penurunan paling besar, sedangkan titik $P_{28}$ merupakan titik dengan penurunan paling kecil

3. Hasil hitungan pergerakan vertikal antar kala I dan III

Nilai pergerakan vertikal titik pantau jembatan antar kala I dan III memiliki rentang nilai $-9,93$ mm s.d. $-80,97$ mm. Hasil pergerakan vertikal yang ditunjukkan 18 titik pantau jembatan memiliki tren pergerakan seragam turun dengan titik $\mathrm{P}_{8}$ merupakan titik dengan penurunan paling besar, sedangkan titik $P_{12}$ merupakan titik dengan penurunan paling kecil. Hasil perhitungan nilai pergerakan yang terjadi pada antar kala I dan III bila dikorelasikan dengan hasil skenario perhitungan yang lain merupakan hasil penjumlahan nilai pergerakan yang terjadi pada antar kala I dan II dan kala II dan III. Oleh karena itu dapat dikatakan bahwa hasil nilai pergerakan antar kala I dan III 
Yacob V. Hayer ${ }^{1 *}$, T. Aris Sunantyo ${ }^{2}$, dan Nurrohmat Widjajanti ${ }^{3}$

merupakan nilai pergerakan total kala I s.d. kala III pengamatan deformasi Jembatan Penggaron.

4. Hasil hitungan pergerakan vertikal antar kala III dan IV

Nilai pergerakan vertikal titik pantau jembatan antar kala III dan IV memiliki rentang nilai $89,35 \mathrm{~mm}$ s.d. $3,05 \mathrm{~mm}$. Hasil pergerakan vertikal yang ditunjukkan 18 titik pantau jembatan memiliki tren pergerakan yang berbeda-beda. Tren yang terjadi cenderung turun dengan titik P8kanan merupakan titik dengan penurunan paling besar, sedangkan titik P16 merupakan titik dengan penurunan paling kecil.

5. Hasil hitungan pergerakan vertikal antar kala I dan IV

Nilai pergerakan vertikal titik pantau jembatan antar kala I dan IV memiliki rentang nilai -7,16 $\mathrm{mm}$ s.d. $-170,32$. Hasil pergerakan vertikal yang ditunjukkan 18 titik pantau jembatan memiliki tren pergerakan seragam turun dengan titik Pskanan merupakan titik dengan penurunan paling besar, sedangkan titik $P_{12}$ merupakan titik dengan penurunan paling kecil. Berdasarkan uraian sebelumnya dapat dilihat bahwa seluruh pola pergerakan antar kala memiliki ketelitian pergerakan yang sama. Ketelitian pergerakan yang terjadi memiliki rentang nilai $0,64 \mathrm{~mm}$ s.d. $1,50 \mathrm{~mm}$ dengan titik $\mathrm{P}_{12}$ dan $\mathrm{P}_{12 \mathrm{kanan}}$ memiliki nilai simpangan baku paling kecil sedangkan titik $P_{0}$ memiliki nilai simpangan baku yang paling besar. Berdasarkan hasil perhitungan pergerakan vertikal pada antar kala I dan IV memiliki nilai pergerakan yang paling besar pada seluruh skenario antar kala. Hal ini dikarenakan perhitungan pergerakan vertikal antar kala I-IV menggunakan hasil tinggi dan ketelitian titik pantau pada kala pertama (Januari 2014) dan kala terakhir (Maret 2015) titik-titik pantau Jembatan Penggaron dengan rentang waktu antar kala 14 bulan.

\section{Hasil Perhitungan Kecepatan dan Percepatan Pergerakan Vertikal}

Perhitungan kecepatan dan percepatan pergerakan vertikal dilakukan pada kala I s.d. kala IV untuk mengetahui nilai kecepatan, simpangan baku kecepatan dan percepatan dari titik-titik pantau pada saat pengamatan awal sampai dengan pengamatan terakhir.

1. Kecepatan Pergerakan Vertikal Antar Kala I dan II

Nilai kecepatan pergerakan vertikal titik pantau mempunyai rentang $-3,04 \mathrm{~mm} /$ bulan s.d. $-50,60$ $\mathrm{mm} / \mathrm{bulan}$, sedangkan nilai simpangan baku mempunyai rentang $0,92 \mathrm{~mm} /$ bulan s.d. 3,29 $\mathrm{mm} /$ bulan. Hasil perhitungan menunjukkan arah pergerakan seragam turun. Gambar 3 menunjukkan visualisasi kecepatan pergerakan vertikal antar kala I dan kala II titik pantau Jembatan Penggaron.

Pada Gambar 1 ditampilkan visualisasi kecepatan pergerakan vertikal antar kala I dan kala II. Pergerakan vertikal titik pantau pada kanan jembatan (P4kanan s.d. $P_{32 k a n a n)}$ cenderung memiliki tren yang lebih besar daripada tren pergerakan vertikal titik pantau pada kiri jembatan. Hal ini disebabkan jumlah kendaraan yang melintasi jalur tersebut (arah Solo) lebih banyak dibandingkan dengan jumlah kendaraan yang melintas pada jalur yang menuju ke Semarang (Saputra, 2016).

2. Kecepatan Pergerakan Vertikal Antar Kala II dan III

Nilai kecepatan pergerakan vertikal titik pantau mempunyai rentang $-1,09 \mathrm{~mm} /$ bulan s.d. $-30,37$ $\mathrm{mm} / \mathrm{bulan}$, sedangkan nilai simpangan baku mempunyai rentang $0,56 \mathrm{~mm} /$ bulan s.d. 3,29 $\mathrm{mm} /$ bulan. Hasil perhitungan menunjukkan arah pergerakan seragam turun. Gambar 4 menunjukkan kecepatan pergerakan vertikal antar kala II dan kala III titik pantau Jembatan Penggaron.

Pada Gambar 2 ditampilkan kecepatan pergerakan vertikal antar kala II dan kala III. Pada gambar tersebut dapat dilihat arah pergerakan memiliki tren seragam turun. Pergerakan vertikal titik pantau pada kanan

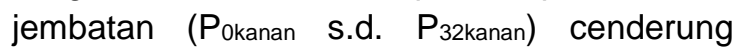
memiliki tren yang lebih besar daripada tren pergerakan vertikal titik pantau pada kiri jembatan. 


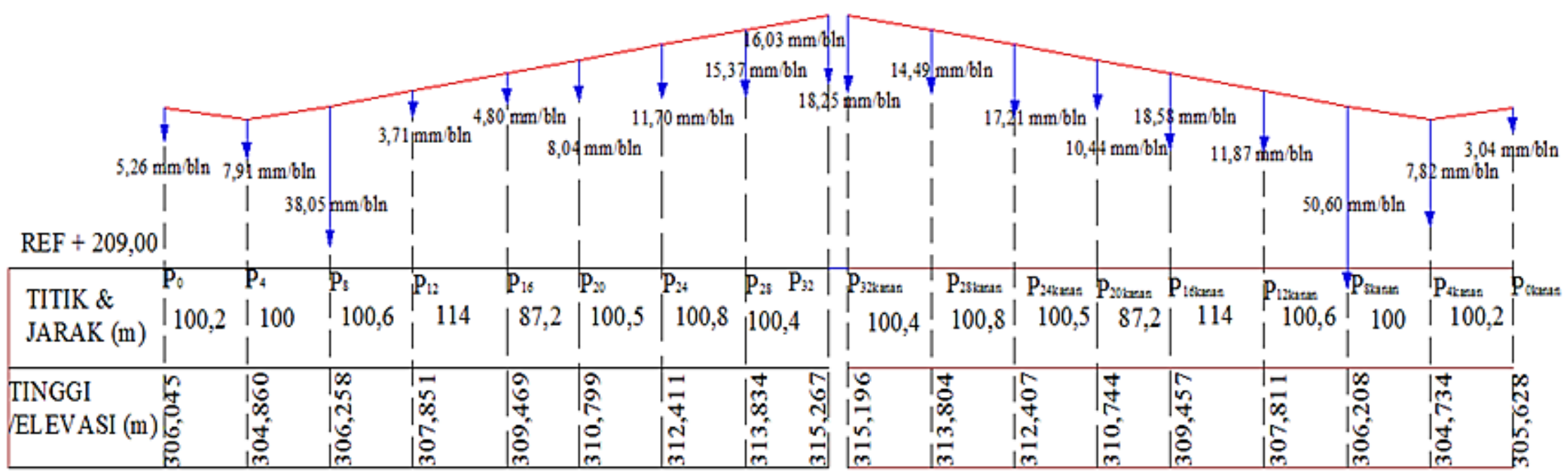

SKALA : HORIZONTAL 1:1000 VERTIKAL 1:100

Gambar 1. Kecepatan pergerakan vertikal antar kala I dan kala II titik pantau jembatan

Keterangan Gambar 1 :

\begin{abstract}
: arah kecepatan pergerakan turun
: arah kecepatan pergerakan naik
\end{abstract}

$30 \mathrm{~mm}$ 


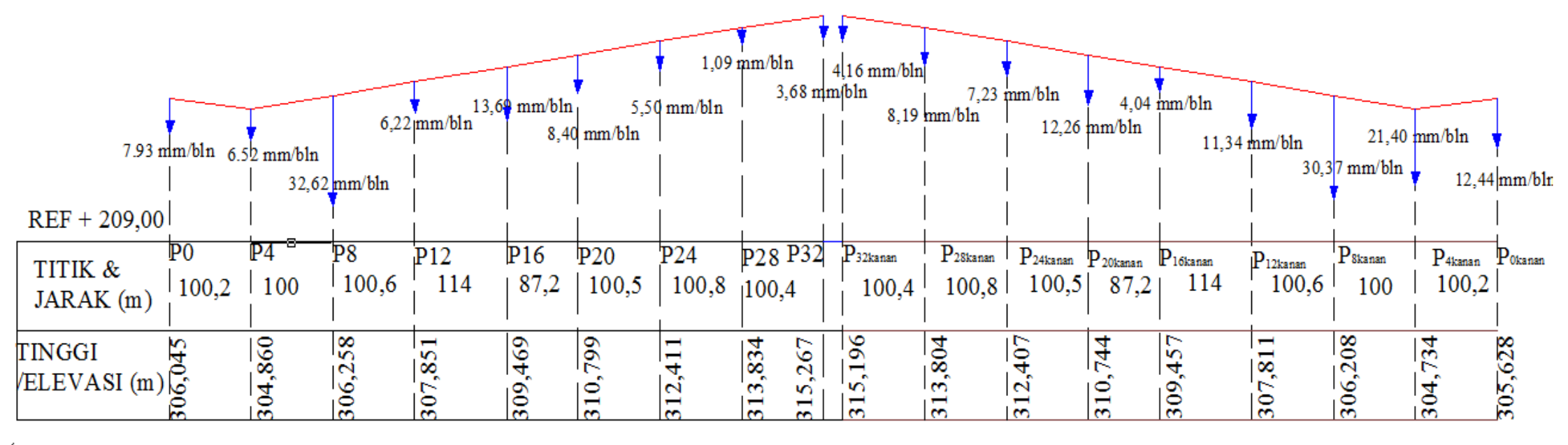

Y

SKALA : HORIZONTAL 1:1000 VERTIKAL 1:100

Gambar 2. Kecepatan pergerakan vertikal antar kala II dan kala III titik pantau jembatan

Keterangan gambar 2 :

: arah kecepatan pergerakan turun
: arah kecepatan pergerakan naik

$: 30 \mathrm{~mm}$ 
3. Kecepatan Pergerakan Vertikal Antar Kala I dan III

Nilai kecepatan pergerakan vertikal titik pantau mempunyai rentang $-4,97 \mathrm{~mm} /$ bulan s.d. $-40,48$ $\mathrm{mm} /$ bulan, sedangkan nilai simpangan baku mempunyai rentang $0,18 \mathrm{~mm} /$ bulan s.d. 0,64 $\mathrm{mm} /$ bulan. Hasil perhitungan menunjukkan arah pergerakan seragam turun. Gambar 3 menunjukkan kecepatan pergerakan vertikal antar kala I dan kala III titik pantau Jembatan Penggaron.

Pada gambar 3 ditampilkan kecepatan pergerakan vertikal pada antar kala I dan kala III. Pada gambar itu dapat dilihat arah pergerakan memiliki tren seragam turun. Pergerakan vertikal titik pantau pada kanan jembatan (Pokanan s.d. P32kanan) memiliki tren yang lebih besar daripada tren pergerakan vertikal titik pantau pada kiri jembatan.

4. Kecepatan Pergerakan Vertikal Antar Kala III dan IV

Nilai kecepatan pergerakan vertikal titik pantau mempunyai rentang 3,05 mm/bulan s.d. -89,35 $\mathrm{mm} /$ bulan, sedangkan nilai simpangan baku mempunyai rentang $1,35 \mathrm{~mm} /$ bulan s.d. 4,82 $\mathrm{mm} /$ bulan. Hasil perhitungan menunjukkan arah pergerakan cenderung turun. Gambar 4 menunjukkan kecepatan pergerakan vertikal antar kala III dan kala IV titik pantau Jembatan Penggaron.

Pada Gambar 4 ditampilkan kecepatan pergerakan vertikal pada antar kala III dan kala IV. Pada gambar itu dapat dilihat arah pergerakan memiliki tren cenderung turun. Pergerakan vertikal titik pantau pada kanan jembatan cenderung memiliki tren yang lebih besar daripada tren pergerakan vertikal titik pantau pada kiri jembatan.

5. Kecepatan Pergerakan Vertikal Antar Kala I dan IV

Nilai kecepatan pergerakan vertikal titik pantau mempunyai rentang $-0,51 \mathrm{~mm} /$ bulan s.d. $-12,17$ $\mathrm{mm} /$ bulan, sedangkan nilai simpangan baku mempunyai rentang $0,12 \mathrm{~mm} /$ bulan s.d. 0,44 $\mathrm{mm} /$ bulan. Hasil perhitungan menunjukkan arah pergerakan seragam turun. Gambar 5 menunjukkan pergerakan vertikal antar kala I dan kala IV titik pantau Jembatan Penggaron.

Pada Gambar 5 ditampilkan kecepatan pergerakan vertikal pada antar kala I dan kala IV. Pada gambar itu dapat dilihat arah pergerakan memiliki tren seragam turun.
Pergerakan vertikal titik pantau pada kanan jembatan cenderung memiliki tren yang lebih besar daripada tren pergerakan vertikal titik pantau pada kiri jembatan. Visualisasi kecepatan pergerakan vertikal untuk seluruh skenario antar kala dapat dilihat pada Gambar 6.

Secara keseluruhan hasil perhitungan menunjukkan arah pergerakan vertikal yang cenderung turun. Untuk rentang nilai kecepatan pergerakan terkecil terjadi pada antar kala I dan IV dikarenakan memiliki rentang waktu antar kala yang lebih lama (14 bulan) sedangkan rentang nilai kecepatan pergerakan terbesar terjadi pada antar kala III dan IV. Titik $\mathrm{P}_{8}$ dan $P_{8 k a n a n}$ merupakan titik pantau yang memiliki nilai kecepatan pergerakan terbesar sedangkan titik Pokanan pada antar kala I dan II, $\mathrm{P}_{28}$ pada antar kala II dan III, $\mathrm{P}_{12}$ pada antar kala I dan III, $\mathrm{P}_{20}$ dan $\mathrm{P}_{24}$ pada antar kala III dan IV, $\mathrm{P}_{12}$ pada antar kala I dan IV merupakan titik pantau yang memiliki nilai kecepatan pergerakan terkecil. 


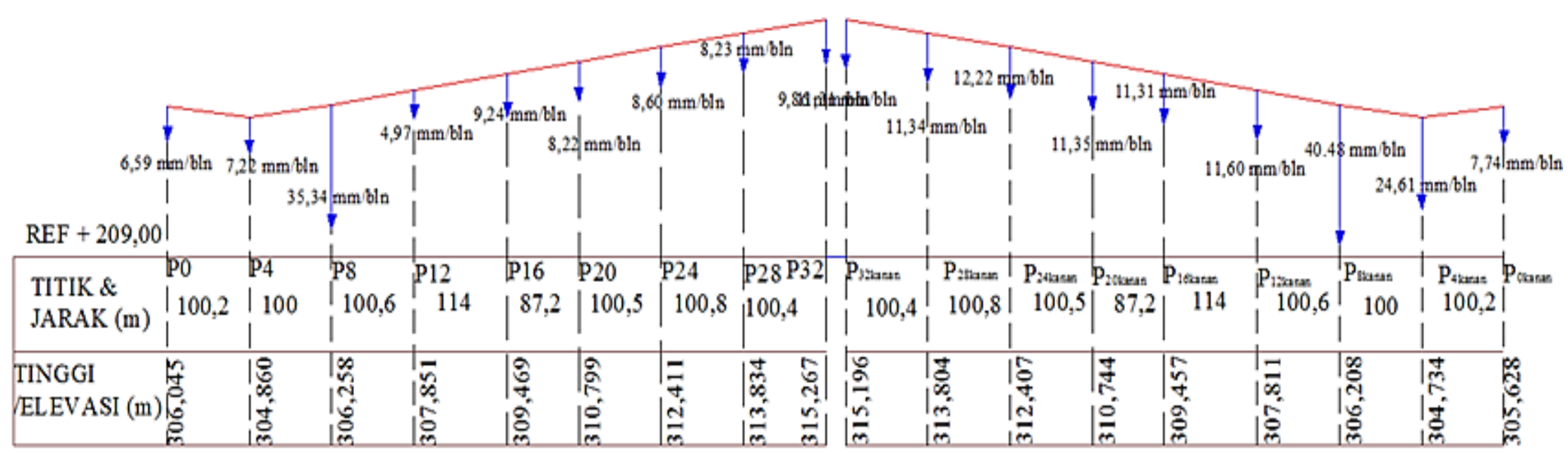

SKALA : HORIZONTAL 1:1000 VERTIKAL 1:100

Gambar 3. Kecepatan pergerakan vertikal antar kala I dan kala III titik pantau jembatan

Keterangan gambar 3 :

\begin{abstract}
: arah kecepatan pergerakan turun
: arah kecepatan pergerakan naik
\end{abstract}

$30 \mathrm{~mm}$ 


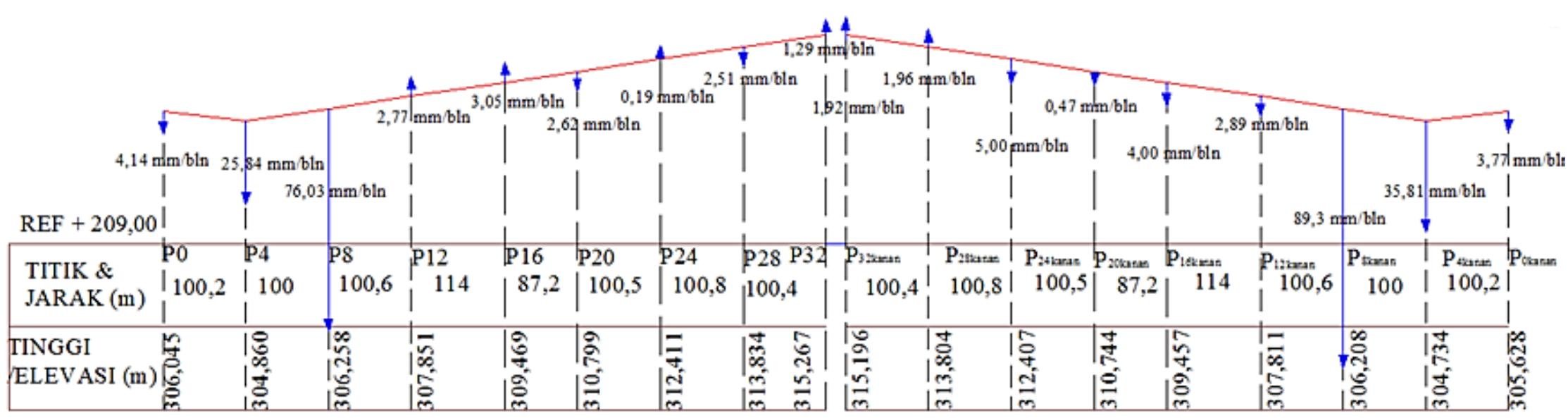

SKALA : HORIZONTAL 1:1000 VERTIKAL 1:100

Gambar 4. Kecepatan pergerakan vertikal antar kala III dan kala IV titik pantau jembatan

Keterangan gambar 4 :

\begin{abstract}
: arah kecepatan pergerakan turun
: arah kecepatan pergerakan naik
\end{abstract}

: $30 \mathrm{~mm}$ 
Yacob V. Hayer ${ }^{1 \star}$, T. Aris Sunantyo ${ }^{2}$, dan Nurrohmat Widjajanti ${ }^{3}$

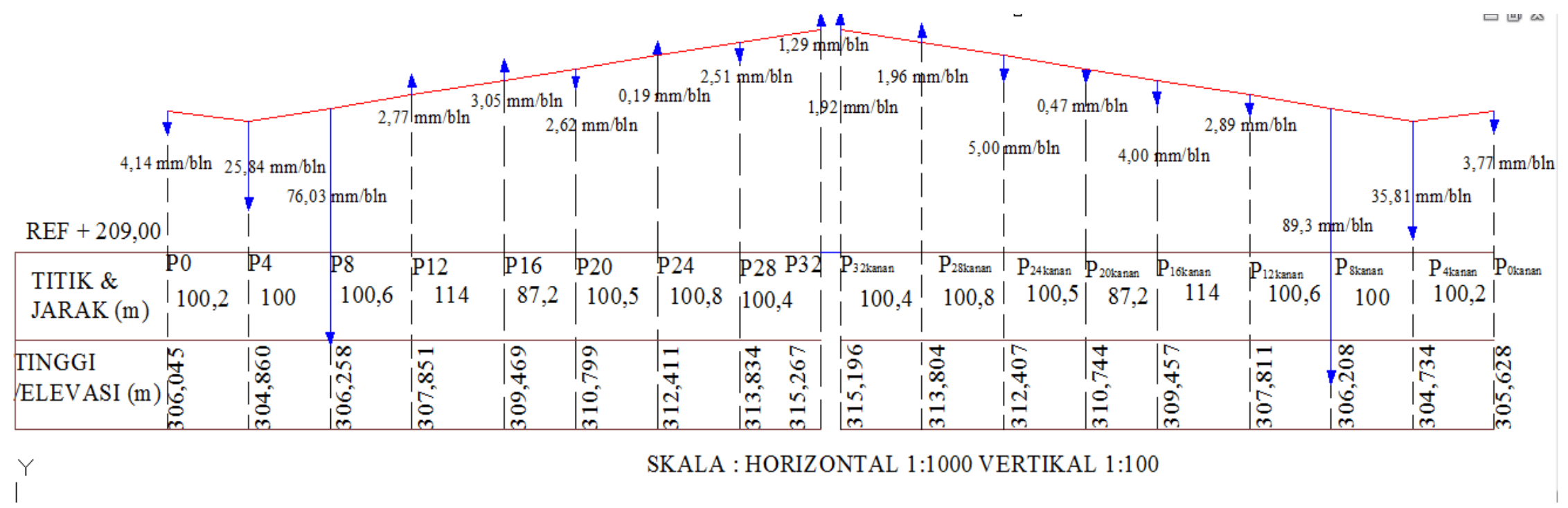

Gambar 5. Kecepatan pergerakan vertikal antar kala I dan kala IV titik pantau jembatan

Keterangan gambar 5 :

\begin{abstract}
:arah kecepatan pergerakan turun
: arah kecepatan pergerakan naik
\end{abstract}

: $30 \mathrm{~mm}$ 


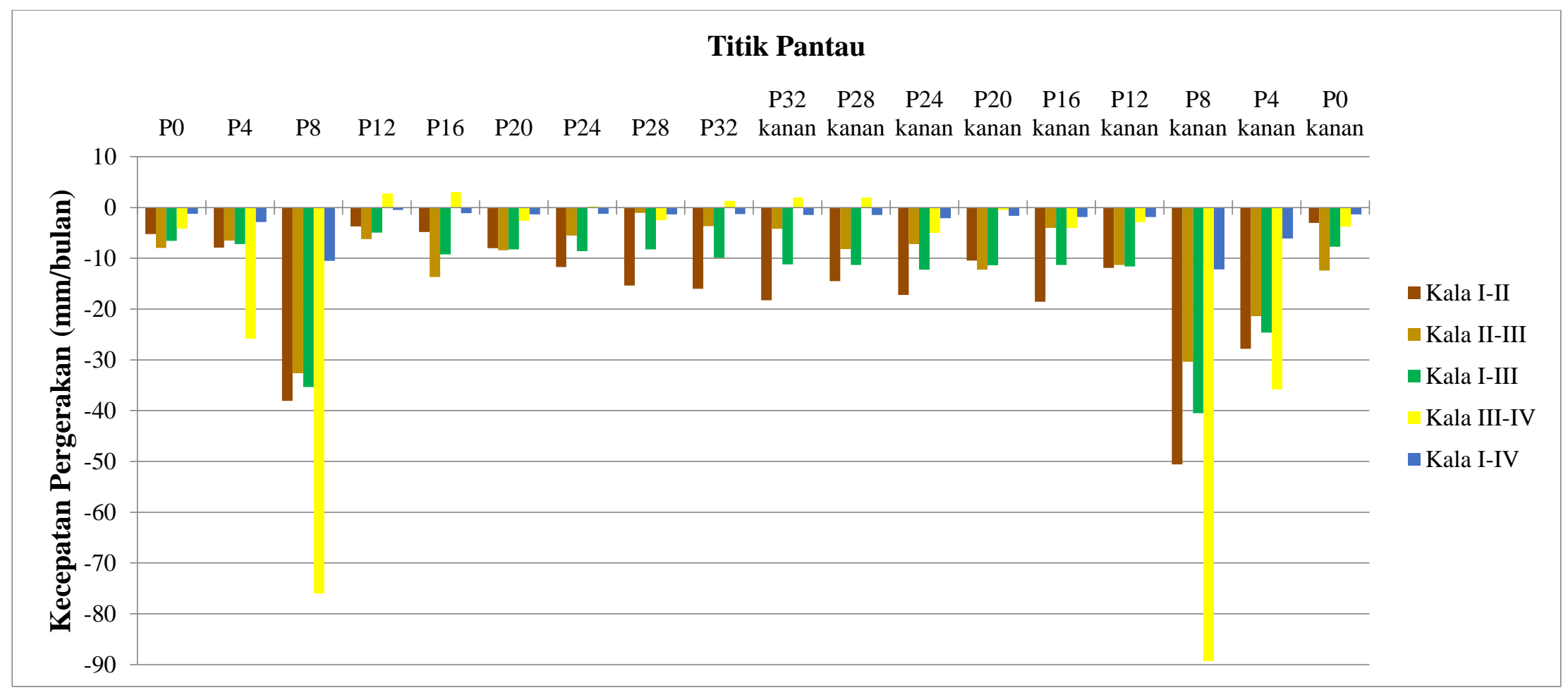

Gambar 6. Visualisasi kecepatan pergerakan vertikal titik pantau

Keterangan Gambar 6 :

$\begin{array}{ll}0 \text { s.d. } 10 & \text { : nilai kecepatan pergerakan yang mengindikasikan arah kecepatan pergerakan naik } \\ 0 \text { s.d. }-90 & \text { : nilai kecepatan pergerakan yang mengindikasikan arah kecepatan pergerakan turun }\end{array}$ 
Yacob V. Hayer ${ }^{1 \star}$, T. Aris Sunantyo ${ }^{2}$, dan Nurrohmat Widjajanti ${ }^{3}$

Setelah didapatkan nilai kecepatan dan simpangan bakunya maka bisa dihitung nilai kecepatan dan percepatan rata-rata pergerakan vertikal yang disajikan pada Tabel 2.

Tabel 1. Kecepatan $(\bar{V})$ dan percepatan ratarata $(\bar{a})$

\begin{tabular}{|l|c|c|}
\hline & $\begin{array}{c}\overline{\boldsymbol{V}} \\
\text { (mm/bulan) }\end{array}$ & $\begin{array}{c}\overline{\boldsymbol{a}} \\
\text { (mm/bulan }\end{array}$ \\
\hline Kala I dan II & $-7,08$ & $-7,08$ \\
\hline Kala II dan III & $-4,93$ & $-4,93$ \\
\hline Kala I dan III & $-6,00$ & $-3,00$ \\
\hline Kala III dan IV & $-6,03$ & $-6,03$ \\
\hline Kala I dan IV & $-1,29$ & $-0,09$ \\
\hline
\end{tabular}

Tabel 2. menunjukkan nilai kecepatan dan percepatan rerata pada semua pola pergerakan antar kala. Nilai kecepatan dan percepatan rata-rata menunjukkan tren yang sama, dimana nilai kecepatan dan percepatan rata-rata terkecil terjadi pada antar kala I-IV sedangkan nilai kecepatan dan percepatan rata-rata terbesar terjadi pada antar kala I dan II.

\section{Hasil Uji Signifikansi Beda Dua Parameter}

Setelah didapatkan vektor pergerakan hasil hitungan sebelumnya maka perlu dilakukan uji statistik untuk menentukan apakah pergerakan yang terjadi signifikan atau tidak. Uji statistik yang digunakan adalah uji signifikansi beda dua parameter.

Pada penelitian ini, uji signifikansi beda dua parameter menggunakan derajat kebebasan 22 dengan tingkat kepercayaan 95\% sehingga nilai Tabel $t$-Student adalah 2,074. Hasil evaluasi pergerakan vertikal Jembatan Penggaron menunjukkan bahwa Mayoritas hasil uji signifikansi beda dua parameter titik pantau ditolak yang berarti titik pantau mengalami pergerakan yang signifikan.

\section{PENUTUP}

Berdasarkan pada hasil penelitian yang telah dilakukan, maka kesimpulan dan saran adalah sebagai berikut:

\section{Kesimpulan}

Hasil pendeteksian pergerakan vertikal pada Jembatan Penggaron menunjukkan bahwa: Besar vektor pergerakan vertikal 18 titik pantau Jembatan Penggaron memiliki nilai 3,1 $\mathrm{mm}$ s.d. $170,3 \mathrm{~mm}$ dengan arah pergerakan mayoritas turun.

Hasil perhitungan kecepatan dan percepatan pergerakan vertikal pada Jembatan Penggaron menunjukkan besar kecepatan pergerakan vertikal memiliki nilai 3,05 $\mathrm{mm} /$ bulan s.d. $89,35 \mathrm{~mm} /$ bulan dengan arah pergerakan mayoritas turun. Besar kecepatan pergerakan vertikal rata-rata antar kala I dan II adalah $7,08 \mathrm{~mm} /$ bulan, kala II dan III adalah $4,93 \mathrm{~mm} /$ bulan, kala I dan III adalah 6,00 $\mathrm{mm} /$ bulan, kala III dan IV adalah 6,03 $\mathrm{mm} /$ bulan, dan kala I dan IV adalah 1,29 $\mathrm{mm} /$ bulan. Besar percepatan pergerakan vertikal rata-rata antar kala I dan II adalah 7,08 $\mathrm{mm} /$ bulan2, kala II dan III adalah 4,93 $\mathrm{mm} /$ bulan2, kala I dan III adalah 3,00 $\mathrm{mm} /$ bulan2, kala III dan IV adalah 6,03 $\mathrm{mm} /$ bulan2 dan kala I dan IV adalah 0,09 $\mathrm{mm} /$ bulan2.

Hasil evaluasi pergerakan vertikal Jembatan Penggaron menunjukkan bahwa Mayoritas hasil uji signifikansi beda dua parameter titik pantau ditolak yang berarti titik pantau mengalami pergerakan yang signifikan.

\section{Saran}

Berdasarkan penelitian ini, terdapat beberapa saran yang dapat diberikan untuk kemajuan penelitian selanjutnya, yaitu 1) diperlukan data penunjang lainnya seperti data lalu lintas, data suhu udara pada saat pengukuran sipat datar. 2) diperlukan data dengan tingkat ketelitian yang tinggi dan diperlukan penggunaan peralatan (waterpass, rambu ukur, dll.) pada saat pengumpulan data yang disesuaikan dengan SNI-JKV. 3) diperlukan adanya kajian mengenai pergerakan vertikal titik kontrol (BM.PGR1 dan BM.PGR2).

\section{UCAPAN TERIMAKASIH}

Pada kesempatan ini saya mengucapkan terima kasih kepada bapak Dr. Ir. T. Aris Sunantyo, M.Sc. sebagai dosen pembimbing tesis pertama dan Ir. Nurrohmat Widjajanti, M.T., Ph.D. sebagai dosen pembimbing tesis kedua yang selalu bersedia memberikan bimbingan, arahan serta membagi ilmu dan ide dalam situasi apapun kepada 
penulis orang tua yang selalu memberikan dukungan, doa, dan motivasi untuk penulis; serta semua pihak yang telah membantu selama proses penyusunan penelitian ini yang tidak bisa disebutkan satu-persatu..

\section{DAFTAR PUSTAKA}

Badan Standarisasi Nasional, 2004, SNI 196988-2004, tentang Jaring Kontrol Vertikal dengan Metode Sipat Datar.

Basuki, S., 2011, Ilmu Ukur Tanah, Cetakan ke2, Gadjah Mada University Press, Yogyakarta.

Balodimos, G.G., Georgopoulos, G., Telioni, V., 1994, Kinematic Adjustment of Levelling Control Networks, Survey Review 32/253.

Caspary, W.F., 1987, Concepts of Network and Deformation Analysis, Monograph 11, School of Surveying the University of New South Wales.

Ghilani, C.D., 2010, Adjustment Computations Spatial Data Analysis, $5^{\text {th }}$ ed., John Wiley \& Sons, Inc., USA.

Kuang, S., 1996, Geodetik Network Analysis and Optimal Design : Concepts and Applications, Ann Arbor Press Inc., USA.

Saputra, I.Y., 2016, Tol Ungaran-Bawen dilalui $12.000 \quad K e n d a r a a n / H a r i$, Semarangpos.com, Diakses pada 25 Oktober 2016, http://semarangpos.com/tol-ungaranbawen-dilalui-12000-kendaraan/hari.

Widjajanti N., 1997, "Analisis Deformasi Status Geometrik Dua Dimensi dengan Pendekatan Generalisasi Matriks Kebalikan", Tesis Magister, Program Pascasarjana Institut Teknologi Bandung, Bandung.

Widjajanti, N., 2001., Deformasi Vertikal (dengan Pendekatan Geodetik, Diktat Kuliah Teknik Geodesi, Universitas Gadjah Mada, Yogyakarta.

Widjajanti,N.,2010.,Deformation Analysis of Offshore Platform Using GPS Technique and Its Application in Structural Integrity Assesment, Ph.D Disertasi, Universiti Teknologi Petronas, Malaysia.

Wolf, P.R., 1980, Adjustment Computation, P.B.L. Publishing Co., Wisconsin.

Wolf, P.R. dan Ghilani C.D., 1997, Adjustment Computations Statistics and Least Squares in Surveying and GIS, Jhon Wiley \& Son Inc, New York. 